Nwidu et al., Afr J Tradit Complement Altern Med. (2014) 11(2):257-263

http://dx.doi.org/10.4314/ajtcam.v11i2.5

\title{
ANTIDIARRHEAL MECHANISM AND IONIC PROFILE OF CARPOLOBIA LUTEA ETHANOLIC STEM-BARK EXTRACT IN RATS.
}

\section{Lucky Legbosi Nwidu $^{a}$, Orodje Onomor Ukirib ${ }^{b}$ Clenilson Martins Rodrigues ${ }^{c}$ and Wagner Vilegas ${ }^{d}$}

\author{
${ }^{\mathrm{ab}}$ Department of Pharmacology and Toxicology, Faculty of Pharmacy, Niger Delta University, Wilberforce Island \\ Bayelsa State, Nigeria; P.O. Box 10935, Port Harcourt Nigeria; ${ }^{\text {dd }}$ Department of Organic Chemistry, Chemistry \\ Institute, São Paulo State University, UNESP-CP 355, CEP 14801-970, Araraquara, SP, Brazil. \\ *E-mail: menelucky@yahoo.com;
}

\begin{abstract}
Background: The stem-bark extract of Carpolobia lutea (Polygalaceae), used in ethno-medicine as anti-diarrhea was pharmacologically evaluated. This was the first report of assessment of the ethanolic stem extract (ESE), of $C$. lutea as anti-diarrhoeal agent in rats. The anti-diarrhoeal effects, acute toxicity and ionic profile are investigated and reported.

Materials and Methods: The acute toxicity was established using Lock's method. The anti-diarrhoeal effects were demonstrated using castor oilinduced diarrheal and fluid accumulation and its effect on normal intestinal transit. The mechanism elucidated using yohimbine, isosorbide dinitrate, and diphenoxylate. The elemental and ionic profile of ESE was established using inductively coupled argon-plasma emission spectrometer and potentiometric titration respectively. The finger print of ESE was revealed by Jasco (Tokyo, Japan), HPLC and active compounds by phytochemical screening using standard procedure.

Results: The $\mathrm{LD}_{50}$ obtained is $866.025 \mathrm{mg} / \mathrm{kg}$ (i.p). The doses of $43.3,86.6$, and $173.2 \mathrm{mg} / \mathrm{kg}$ of ESE showed inhibition of castor oil-induced diarrheal ( $\mathrm{p}<0.05-0.001)$. The most abundant cations in the extract are potassium and phosphorus $(1.00 \pm 0.01$ and $0.80 \pm 0.030 \mathrm{mg} / \mathrm{g}$ respectively); while the most abundant anions are phosphate and sulphate ( $33.50 \pm 7.09$ and $7.19 \pm 3.29 \mathrm{mg} / \mathrm{g}$ respectively). The HPLC fingerprint of ESE revealed UV spectra of biomolecules. Phytochemical screening revealed presence of saponins, polyphenols and glycosides.

Conclusion: These investigations indicate presence of bioactive and elemental substances which could play major role in diarrheal management. This investigation justifies the use of stem-bark of $C$. lutea in illicit gin (akpatashi), among the Effiks in Nigeria as antidiarrheal.
\end{abstract}

Key words: Carpolobia lutea, stem-bark extract, antidiarrheal, elemental and ionic profile.

\section{Introduction}

Diarrhea remains a major health challenge to the populations of most poor tropical countries and is the leading cause of morbidity and mortality in all age groups, with as much as four million cases occurring each year (Farthing, 2002). Heinrich et al. (2005) reported that WHO estimates that 3-5 billion diarrheal cases occur yearly ( 1 billion in children less than 5 years of age), and that approximately 5 million deaths are due to diarrhea annually (2.5 million in children less than five years of age). Martinez et al. (1998) demonstrated that, the form of treatment that is administered primarily to children, mothers inclusive are herbal remedies. The use of herbal substances for the treatment of ailments among Africans is as old as antiquities. The accessibility of herbal medicine practitioners, their inexpensive products and the consideration of traditional practice as part of African heritage by the generality of the population have created a big market for herbal products in Africa. Plants play important role in drug discovery, and their search through logical strategy in the search for new drugs (Andreo et al., 2006).

Carpolobia lutea G. Don (Polygalaceae) is a small tree distributed in West and Central African tropics. It grows in rainforest and Guinea savannah of Sierra Leon to Cameroon. It occurred as a dense overgrowth or, as an evergreen shrub or small tree that is up to $5 \mathrm{~m}$ high. $C$. lutea stembark has been used for headaches, general pain and the prevention of sleep due to fatigue. The root is reported to have aphrodisiac activity (Etebong et al., 2012). It has analgesic, androgenic properties, and is reputed to cure rheumatism, fever and to combat sterility. Others include insanity, dermal infection, venereal diseases, and promotion of child birth; taeniafuge and vermifuge (Burkill 1985; Etukudo 2003; Muanya \& Odukoya, 2008). Pharmacological reports of investigations on the activities of the leaf material include anti-inflammatory and anti-arthritis (Iwu \& Ayanwu, 1982), anti-ulcerogenic and anti-diarrhea (Nwafor and Bassey, 2007), anti-hemorrhoid property (Soladoye et al., 2011), gastroprotective (Nwidu and Nwafor, 2009); antinociceptive (Nwidu et al., 2011a); antidiarrheal mechanism (Nwidu et al., 2011b), antimicrobial (Nwidu et al., 2012a); neuropharmacological effects (Nwidu et al., 2012b), the amino acids, antioxidants and ionic profile (Nwidu et al., 2012c), anti-ulcer effects (Nwidu et al., 2012d) and anti-inflammatory and anti-pyretic effects (Nwidu et al., 2012e). Two new cinnamoyl 1-deoxyglucosides and cinnamic acid have been isolated from the leaf by semi-preparative HPLC, and the structures established by NMR (Nwidu et al., 2012b). In this study, we evaluated the fingerprint of the ESE, preliminary phyto-chemical screening, elemental and anionic evaluation and anti-diarrheal profile of the stem-bark extract of the plant on castor oil-induced diarrhea and fluid accumulation in addition to its activity on normal intestinal transit in rats. The choice of ethanolic extract is predicated on soaking the stem-back in illicit gin (akpatashi) by local people who use the plant in Nigeria.

\section{Materials and Methods Collection of plant materials}

Collection of the plant was done in January, 2009. The stem-bark was collected from Itak- Ikot Akap village in Ikono Local Government Area of Akwa Ibom State. The plant was collected by an Herbalist Mr. Okon Etefie attached to Pharmacognosy Department in the University of Uyo, and identified by a Botanist named Dr (Mrs.) Margret Bassey of Botany Department in the University of Uyo. A voucher specimen (UUH 998), was 
http://dx.doi.org/10.4314/ajtcam.v11i2.5

deposited at the University Herbarium. The stem-bark was air-dried and powdered. The pulverized plant material were stored at room temperature until used.

Preparation and extraction of plant materials

The stem-bark collected was air-dried and pulverized using harmer mill. The powder plant materials were weighed using weighing balance (BG 4000). Five hundred grams of the stem-bark was weighed and immersed in 3 x $500 \mathrm{ml}$ of ethanol (99.8\%) for $72 \mathrm{hrs}$. The soaked extract was shaken twice daily. The supernatant were filtered using Whatman filter paper (pore sizes-20-25 $\mu$ ). The filtrate of ethanol solvent was reduced in volume nearly to dryness in a rotatory evaporator (BUCCHI USA), at $40{ }^{\circ} \mathrm{C}$. The residue from filtration process were air-dried for $24 \mathrm{hrs}$, and subjected to the same procedure for three successive time. After which the extract was dried under a flow of nitrogen until constant weight was obtained. The yield was $43.4 \%$. The extract was stored in an air tight container in a refrigerator until used. Prior to pharmacological assay, a sample of extract was dissolved in distilled water and used for the animal experiments.

\section{Finger Print Analysis}

The chromatographic fingerprint of the $C$. lutea stem-bark extract was established using a Jasco (Tokyo, Japan), liquid chromatograph equipped with a PU-2089, quaternary solvent pump, a MD-2010 PAD, and an AS-2055, autsampler injector with a $20 \mu \mathrm{L}$ sample loop. The analytical column was a Phenomenex Synergi Hydro RP18, $(250 \times 4.6 \mathrm{~mm}$ i.d.; $4 \mu \mathrm{m})$, equipped with a Phenomenex security guard column $(4.0 \times 2.0 \mathrm{~mm}$ i.d.). The mobile phase composition was: water (eluent A), and metanol (eluent B), both containing $0.05 \%$ of TFA. The gradient program was linear starting with $0 \%$ B to $100 \%$ B in $60 \mathrm{~min}$. The flow rate was $1.0 \mathrm{~mL} / \mathrm{min}$. EZChrom Elite Data System software (Chromatec, Idstein, Germany) was used for both the operation of detector and for data processing. The stem-bark extract $(2 \mathrm{mg})$, was dissolved in $2 \mathrm{~mL}$ methanol, filtered through a $0.45-\mu \mathrm{m}$ membrane polytetrafluoroethylene (PTFE), filter (Millex), resuspended in $3 \mathrm{~mL}$ of water and $20 \mu \mathrm{L}$ was surrendered to HPLC analysis.

\section{Phytochemical Analysis}

The ESE of $C$. lutea was subjected to qualitative chemical screening using standard procedure to reveal glycosides, polyphenols and saponins (Trease and Evans, 2001).

\section{Elemental analysis of the plant stem-bark}

The elemental component of ESE stem-bark of $C$. lutea was elucidated using the method of Dahlquist \& Knoll, (1978) as reported for the $C$. lutea leaf fractions (Nwidu et al., 2012d).

\section{Determination of ionic content of plant stem-bark}

This determination was carried out by potentiometric titration as previously reported for leaf fractions (Nwidu et al., 2012d).

\section{Animals}

Swiss albino mice weighing between 25-30 g, and adult albino rats (100-150 g), of both sexes were obtained from the Faculty of Pharmacy Animal House, University of Uyo, Uyo, Nigeria. All the animals were housed in standard cages under laboratory condition in Department of Toxicology/Pharmacology in Niger Delta University to acclimatized the animals. All animals used have free access to tap water under standard conditions of $12 \mathrm{~h}$ dark $12 \mathrm{~h}$ light and temperature $(21 \pm 1 \%)$. The animals were fed with pellet feeds (Vita Feed, Ibadan). The experiment were carried out between June to August 2012, in conformity with standard protocol for use of laboratory animals for experiments (Zimmerman, 1983). The protocols were approved by the Niger Delta University, Faculty of Pharmacy Institutional Animal Care and Use Committee which follows the guidelines of Committee for the purpose of control and supervision of experimental animals (CPSCEA; NDUFPAEC No. 2012/004).

\section{Drugs and chemicals}

Castor oil (Finest cold drawn commercial castor oil), Morphine (Morph) (Evans Medical Ltd., Liverpool), solvents from Reidel-de Haen (Germany) of analytical grade were used and while the pure drugs used are: Yohimbine Sigma, Aldrich (St. Louis, USA), Diphenoxylate (diph) and Isosorbide dinitrate, Isordil ${ }^{\circledR}$ (Actavis) (IDN). The ESE of $C$. lutea was dissolved in water and used in the experiment.

\section{Acute toxicity test $\left(\mathbf{L D}_{50}\right)$}

The $\mathrm{LD}_{50}$ of the ESE of $C$. lutea was estimated by procedure described by Lorke 1983, with modification. Albino mice (25-30 g), of either sexes were used. This method involved an initial lethal dose finding procedure, in which the animals were divided into seven groups of three (3), animals per group. Doses of 10, 100, 1000, 2000, 3000, 4000 and $5000 \mathrm{mg} / \mathrm{kg}$ were administered intraperitoneally (i.p), for each group of three mice. The treated animals were monitored for $24 \mathrm{hrs}$, for mortality and general behavioral characteristic indicative of animal toxicity. The $\mathrm{LD}_{50} \mathrm{was}_{\mathrm{s}}$ then estimated by taking the square root of the least dose that killed all the animals, and the highest dose that do not kill any animal/s or the geometric mean 
http://dx.doi.org/10.4314/ajtcam.v11i2.5

of the lowest dose causing death and the highest dose causing no death. That is, $\mathrm{LD}_{50}$ is equal to (highest dose causing no death mutiply by lowest dose causing death) ${ }^{1 / 2}$

\section{Castor oil-induced diarrhea}

Adult albino rats $(100-150 \mathrm{~g})$, fasted for $24 \mathrm{hrs}$, but with free access to water were used. Water was withdrawn 2 hrs to bioassay. The rats were weighed and randomly allocated to seven groups of six rats each. Group I received $10 \mathrm{ml} / \mathrm{kg}$ of distilled water orally (p.o), group II-IV received 43.3, 86.6 and $173.2 \mathrm{mg} / \mathrm{kg}$ of ESE p.o. Group V received $5 \mathrm{mg} / \mathrm{kg}$ of morphine i.p, group VI and VII received $0.5 \mathrm{mg} / \mathrm{kg}$ of diphenoxylate (Diph), and $1 \mathrm{mg} / \mathrm{kg}$ of yohimbine intra-peritoneally respectively $15 \mathrm{~min}$., after oral administration of extract; 30 minutes later diarrhea was induced with $2 \mathrm{ml}$ of castor oil. The onset time of stooling, the total mass of solid, semi-solid and wet faeces and the total faeces were recorded in each group. Diarrheal was evaluated using the procedure of Awouteur et al., (1978).

The parameter observed are: onset time of diarrhea, number of wet feces, the number of semi-solid feces, the total frequency of fecal output and the total number of diarrhea episodes were counted per group for $4 \mathrm{hrs}$. A numerical score based on stool consistency was assigned- 1 (normal stool), 2 (semi-solid stool), and 3 (watery stool). The onset time is measured as the time interval in minutes between the administration of castor oil and the first appearance of diarrhea stool.

\section{Castor oil-induced fluid accumulation}

Intraluminal fluid accumulation was determined by the method of Robert et al., (1976). The rats were fasted for 24hrs, but allowed free access to water. The rats were randomized and allocated to five (5), groups of six (6), rats per group. Group I (negative control); Groups II-V, were subjected to same treatment as in castor oil induced diarrheal above. One hour after the last dose of castor oil the rats were killed by cervical dislocation and the intestine exsanguinated. The small intestine was ligated both at the pyloric sphincter and at the ileocaecal junction, its contents were expelled into a graduated measuring cylinder, the volume and the weight of the intestinal contents were recorded according to the methods of Dicarlo et al., (1994) and Robert et al., (1976).

\section{Small intestinal transit}

Both sexes of male and female albino rats fasted for $24 \mathrm{hrs}$, but allowed free access to water were used for the experiment. The rats were weighed and randomized into nine groups of six rats each. Group I received $10 \mathrm{ml} / \mathrm{kg}$ distilled water orally and 30 minutes later $1 \mathrm{ml}$ of charcoal meal orally. Groups II-IV, received 43.3, 86.6 and $173.2 \mathrm{mg} / \mathrm{kg}$ of ESE of C. lutea p.o. and $1 \mathrm{ml}$ of charcoal meal p.o. one hour after extract adminitration. Groups V-VII, received ESE (86.6 mg/kg p.o.); and 15 minutes later Diphenoxylate $(0.5 \mathrm{mg} / \mathrm{kg}$ p.o.), Isosorbide dinitrate (150 mg/kg p.o.) and Yohimbine $(1 \mathrm{mg} / \mathrm{kg}$ i.p.). Charcoal meal $(1 \mathrm{ml}$ p.o.) was administered to each group 30 minutes later. Group VIII-X, recieved Diphenoxylate (0.5 $\mathrm{mg} / \mathrm{kg}$ p.o.), Isosorbide dinitrate (150 mg/kg p.o.), Yohimbine (1 mg/kg i.p.) and charcoal meal (1 ml p.o.) 30 minutes after the drugs administration to established mechanism antidiarrheal effects of extract. After $30 \mathrm{~min}$, animals were killed by cervical dislocation, and the intestines were removed carefully without stretching and placed lengthwise on dissecting board. The length of the intestine (pyloric sphincter to cecum) and the distance travelled by the charcoal head as a percentage of total length were evaluated for each animal animal, and group means were compared and expressed as percentage inhibition (Lutterodt, 1989).

\section{Statistical analysis}

The results were expressed as the mean value \pm SEM and significant was determined by Tukey's Kramer multiple comparison (Linton et al, 2007). A probability level of less than 0.05 was considered significant.

\section{Results \\ Phytochemistry}

Analytical HPLC-PAD chromatogram recorded at $280 \mathrm{~nm}$ of the compounds of ethanolic stem extract of $C$. lutea after SPE clean-up is shown in Figure 1.The peaks are fingerprint of UV spectra and characteristic of bioactive compounds present in the ESE of $C$. lutea. A preliminary phyto-chemical screening gave positive test for saponins, polyphenols and glycosides.

Table 1: Cation content (mg/g) of Carpolobia lutea aqueous stem extract

\begin{tabular}{|c|c|c|c|c|c|c|c|c|c|c|}
\hline \multirow{3}{*}{$\begin{array}{l}\text { Samples } \\
\text { Mean } \pm \\
\text { SEM }\end{array}$} & \multicolumn{10}{|c|}{ Cation content (mg/L) } \\
\hline & $\mathbf{N a}$ & $\mathbf{K}$ & Mg & $\mathbf{F e}$ & Mn & $\mathbf{C u}$ & $\mathrm{Hg}$ & $\mathbf{P b}$ & $\mathbf{P}$ & $\mathbf{Z n}$ \\
\hline & $\begin{array}{c}0.180 \\
\pm \\
0.020\end{array}$ & $\begin{array}{l}1.00 \\
\pm \\
0.01\end{array}$ & $\begin{array}{l}0.05 \\
\pm \\
0.04\end{array}$ & $\begin{array}{l}0.09 \\
\pm \\
0.003\end{array}$ & $\begin{array}{l}0.005 \\
\pm \\
0.004\end{array}$ & $\begin{array}{l}0.005 \\
\pm \\
0.001\end{array}$ & $<0.001$ & $<0.001$ & $\begin{array}{l}0.800 \\
\pm \\
0.030\end{array}$ & $\begin{array}{l}0.013 \\
\pm \\
0.001\end{array}$ \\
\hline
\end{tabular}


http://dx.doi.org/10.4314/ajtcam.v11i2.5

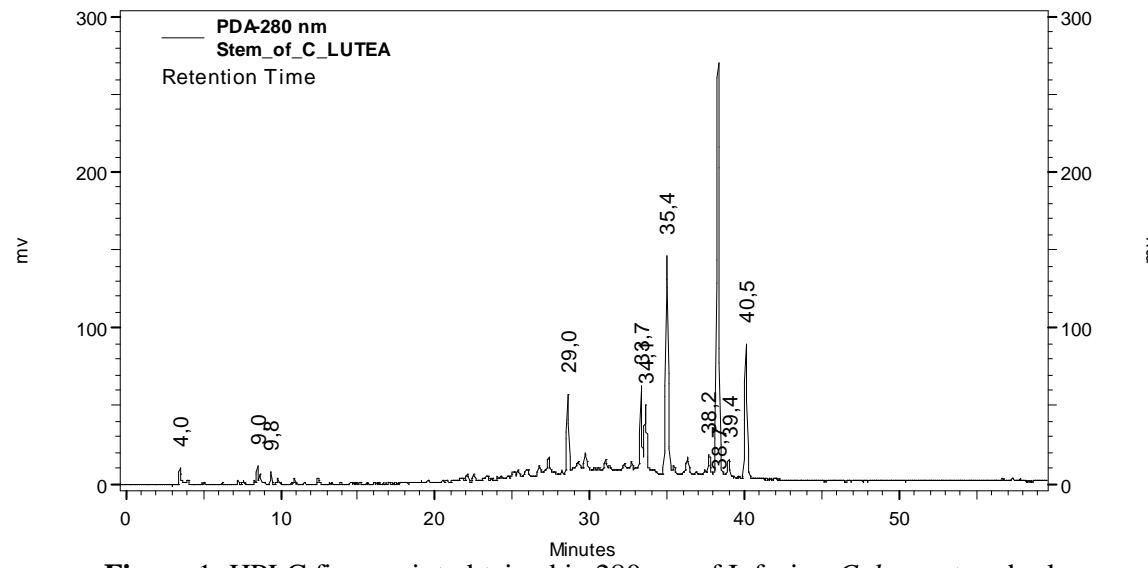

Elemental and anion profile of ESE

Figure 1: HPLC fingerprint obtained in $280 \mathrm{~nm}$ of Infusion C. lutea stem-bark

The results of the elemental and anionic analysis of the plant stem-bark extract are shown in Tables 1 and 2. The results indicate that it contains significant amounts of cations which ranged from $0.05 \pm 0.001 \mathrm{mg} / \mathrm{g}$ (for copper) to $1.00 \pm 0.01$ (for potassium). Heavy metal ion content (lead and mercury) were $<0.001$. Anion contents of the plant ESE includes: $\mathrm{PO}_{4}{ }^{2-}, \mathrm{SO}_{4}{ }^{2-}, \mathrm{CL}^{-}, \mathrm{F}^{-}$, and $\mathrm{NO}^{3-}$ as shown in Table 2 . The results indicate that the ESE contains phosphate $(33.50 \pm 7.09)$, sulphate $(7.19 \pm 3.29)$, chloride $(0.90 \pm 0.02)$, nitrate $(0.97 \pm 0.02)$ and fluoride $(<0.2) \mathrm{mg} / \mathrm{g}$ of stem extract. The most abundant anions are phosphate and sulphate. The $\mathrm{pH}$ of the ESE was estimated as $4.6 \pm 0.05$

Table 2: Anionic content (mg/L)/pH of Carpolobia lutea ethanolic stem-bark extract

\begin{tabular}{|l|l|l|l|l|l|l|}
\hline Samples & \multicolumn{3}{|c|}{ Anions content (mg/L) } & pH of ESE \\
\hline \multirow{2}{*}{$\begin{array}{l}\text { Mean } \pm \\
\text { SEM }\end{array}$} & $\mathbf{P O}_{4}{ }^{2-}$ & $\mathbf{S O}_{4}{ }^{2-}$ & $\mathbf{C L}^{-}$ & $\mathbf{F}^{-}$ & $\mathbf{N O}_{3}{ }^{-}$ & $4.6 \pm 0.05$ \\
\cline { 2 - 6 } & $3.35 \pm 7.09$ & $7.19 \pm 3.29$ & $0.90 \pm 0.02$ & $<0.200$ & $4.6 \pm 0.05$ & \\
\hline
\end{tabular}

Table 3: Effects of ethanolic stem extract (ESE) of C. lutea on Castor oil-induced diarrhea in rats

\begin{tabular}{|c|c|c|c|c|c|}
\hline $\begin{array}{l}\text { Treatment } \\
\text { (Dose } \mathrm{mg} / \mathrm{kg} \text { ) }\end{array}$ & $\begin{array}{l}\text { Onset time of } \\
\text { stooling }(\text { mins) }\end{array}$ & Solid stool (g) & Semi-solid stool (g) & Watery stool (g) & $\%$ inhibition \\
\hline Control & $32.30 \pm 1.90$ & $0.62 \pm 0.25$ & $0.78 \pm 0.38$ & $8.49 \pm 0.92$ & $0 \%$ \\
\hline ESE 43.3 & $28.17 \pm 2.07^{\mathrm{ns}}$ & $0.62 \pm 0.28^{\mathrm{ns}}$ & $0.44 \pm 0.24^{\mathrm{ns}}$ & $4.59 \pm 0.24^{\mathrm{c}}$ & $46 \%$ \\
\hline ESE 86.6 & $28.33 \pm 2.96^{\mathrm{ns}}$ & $0.71 \pm 0.23^{\mathrm{ns}}$ & $0.63 \pm 0.27^{\mathrm{ns}}$ & $3.25 \pm 0.36^{\mathrm{c}}$ & $62 \%$ \\
\hline ESE 173.2 & $27.83 \pm 2.07^{\mathrm{ns}}$ & $1.05 \pm 0.21^{\mathrm{ns}}$ & $0.90 \pm 0.28^{\mathrm{ns}}$ & $2.22 \pm 0.13^{\mathrm{c}}$ & $74 \%$ \\
\hline $\begin{array}{l}\text { ESE } 86.6+ \\
\text { Diph } 0.5\end{array}$ & $120.00 \pm 3.66^{\mathrm{c}}$ & $0.96 \pm 0.43^{\text {ns }}$ & $0.61 \pm 0.24^{\mathrm{ns}}$ & $0.44 \pm 0.24^{c}$ & $95 \%$ \\
\hline ESE 86.6 + Yoh (1) & $121.00 \pm 7.00^{\mathrm{c}}$ & $1.42 \pm 0.24^{\mathrm{ns}}$ & $1.28 \pm 0.27^{\mathrm{ns}}$ & $1.26 \pm 0.27^{\mathrm{c}}$ & $85 \%$ \\
\hline Morphine 5 & $121,00 \pm 7.00^{\mathrm{c}}$ & $1.18 \pm 0.18^{\mathrm{a}}$ & $0.88 \pm 0.12^{\mathrm{ns}}$ & $1.62 \pm 0.04^{\mathrm{c}}$ & $90 \%$ \\
\hline
\end{tabular}

Significance relative to control: ${ }^{\mathrm{a}} \mathrm{p}<0.05,{ }^{\mathrm{b}} \mathrm{p}<0.01,{ }^{\mathrm{c}} \mathrm{p}<0.001 ; \mathrm{ns}=$ not significant. Values represent mean $\pm \mathrm{SEM}(\mathrm{n}=6)$. Diph $=$

Diphenoxylate; Yoh=Yohimbine.

Table 4: Effects of ethanolic stem extracts of $C$. lutea on intestinal fluid accumulation in rats.

\begin{tabular}{|c|c|c|c|}
\hline $\begin{array}{c}\text { Treatment } \\
(\mathbf{m g} / \mathbf{k g})\end{array}$ & $\begin{array}{c}\text { Weight of intestinal } \\
\text { content } \mathbf{( g )}\end{array}$ & $\begin{array}{c}\text { Volume of intestinal } \\
\text { content }(\mathbf{m l})\end{array}$ & Inhibition (\%) \\
\hline Control & $1.76 \pm 0.37$ & $1.98 \pm 0.37$ & $0.00 \%$ \\
\hline ESE 43.3 & $1.40 \pm 0.27^{\text {ns }}$ & $1.70 \pm 0.20^{\text {ns }}$ & $20.40 \%$ \\
\hline ESE 86.6 & $0.80 \pm 0.27^{\text {ns }}$ & $1.10 \pm 0.23^{\text {ns }}$ & $52.00 \%$ \\
\hline ESE 173.2 & $0.97 \pm 0.11^{\text {ns }}$ & $1.25 \pm 0.18^{\text {ns }}$ & $45.00 \%$ \\
\hline Morphine 5 & $0.72 \pm 0.16^{\text {ns }}$ & $1.10 \pm 0.20^{\text {ns }}$ & $59.20 \%$ \\
\hline
\end{tabular}

Significance relative to control: $n s=$ not significant Values represent mean \pm SEM $(n=6)$.

Table 5: Effects of ethanolic stem extract of C lutea on normal intestinal transit in rats.

\begin{tabular}{|c|c|c|c|}
\hline Treatment & Dose $(\mathrm{mg} / \mathrm{kg})$ & Peristaltic index & Inhibition (\%) \\
\hline Control & - & $77.79 \pm 2.88$ & 0.00 \\
\hline ESE & 43.3 & $63.59 \pm 1.79^{\mathrm{b}}$ & 18.25 \\
\hline ESE & 86.6 & $48.02 \pm 2.13^{\mathrm{c}}$ & 38.27 \\
\hline ESE & 173.2 & $54.05 \pm 1.67^{\mathrm{c}}$ & 30.52 \\
\hline ESE + Diph & $86.6+0.5$ & $75.86 \pm 3.61^{\mathrm{ns}}$ & 17.70 \\
\hline ESE + IDN & $86.6+150$ & $64.00 \pm 2.12^{\mathrm{b}}$ & 12.46 \\
\hline ESE + Yoh & $86.6+1.00$ & $68.1 \pm 1.92^{\mathrm{ns}}$ & 33.46 \\
\hline Diph & 0.5 & $51.76 \pm 3.22^{\mathrm{c}}$ & 14.91 \\
\hline IDN & 150 & $66.19 \pm 2.15^{\text {ns }}$ & 38.48 \\
\hline Yoh & 1.00 & $47.86 \pm 2.67^{\mathrm{ns}}$ & \\
\hline
\end{tabular}


http://dx.doi.org/10.4314/ajtcam.v11i2.5

Significance relative to control: ${ }^{\mathrm{a}} \mathrm{p}<0.05 ;{ }^{\mathrm{b}} \mathrm{p}<0.01$; ${ }^{\mathrm{c}} \mathrm{p}<0.001$; values represent mean \pm SEM $(\mathrm{n}=6)$. ESE; Ethanolic stem extract of the various dose range of the extract, Diph; Diphenoxylate, IDN; Isosorbide nitrate, Yoh; Yohimbine

Acute toxicity $\left(\mathbf{L D}_{\mathbf{5 0}}\right)$

The crude extracts produced mortality at the dose of $1500 \mathrm{mg} / \mathrm{kg}$ i.p. The crude ESE was found to be slightly toxic. The $\mathrm{LD}_{50}$ was calculated to be $866.025 \mathrm{mg} / \mathrm{kg}$. The lowest dose $(43.3 \mathrm{mg} / \mathrm{kg})$, middle $(86.6 \mathrm{mg} / \mathrm{kg})$ and highest dose $(173.2 \mathrm{mg} / \mathrm{kg})$, utilised for this bioassay is estimated from $1 / 20^{\text {th }}, 1 / 10^{\text {th }}$ and $1 / 5^{\text {th }}$ of $\operatorname{LD}_{50}(866.025 \mathrm{mg} / \mathrm{kg})$.

\section{Effect on Castor oil-induced diarrhea}

The ESE of C. lutea $(43.3-173.2 \mathrm{mg} / \mathrm{kg}$ ), significantly ( $\mathrm{p}<0.001)$ reduced the number of wet stool (purging frequency) of diarrheal episodes as shown in the Table 3 below. The effect of ESE of $C$. lutea on onset time (Figure 2) reveals only significant effect on watery stool. The extract alone does not have significant effects on onset time of diarrheal, weight of solid and semi-solid stool but only watery stool when compared to the control. The ESE produce a dose dependent inhibition of watery stool with the highest dose of the extract $(173.2 \mathrm{mg} / \mathrm{kg})$, producing $74.0 \%$ inhibition of diarrheal (wet) stool but no significant effect on solid and semi-solid stool. The middle dose of extracts $(86.6 \mathrm{mg} / \mathrm{kg}$ ) plus $0.5 \mathrm{mg} / \mathrm{kg}$ Diphenoxylate or $1 \mathrm{mg} / \mathrm{kg}$ Yohimbine produced a marked increase in onset time of stooling and a reduction in diarrheal stool but no significant effect on solid and semisolid stool. The pure drug morphine $(5 \mathrm{mg} / \mathrm{kg}$ ) prolonged the onset time in diarrheal stool in a statistical significant manner $(\mathrm{p}<0.001)$ and exhibited 90 $\%$ inhibition of diarrhea.

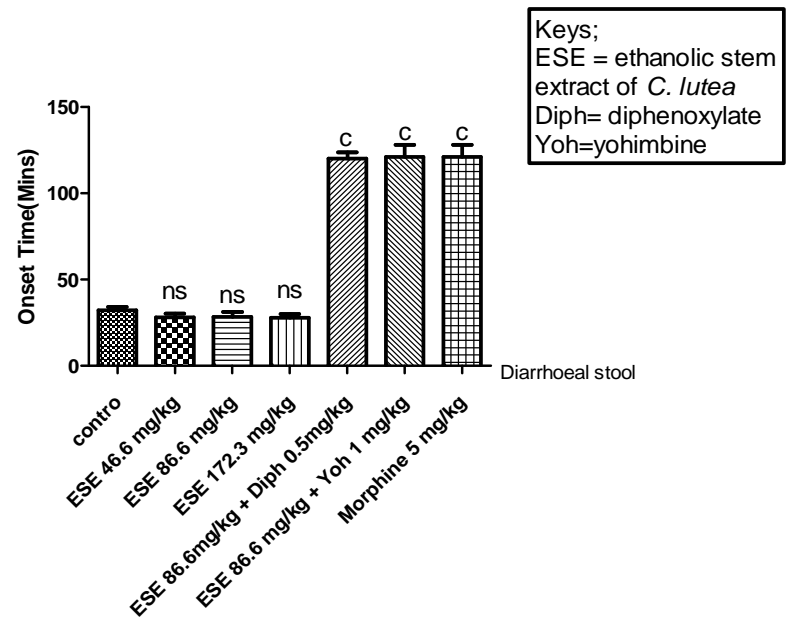

Fig 2: Effect of $C$ lutea stem extract onset time in castor induced diarrhoea

Effect on Castor oil-induced fluid accumulation (Intestinal fluid accumulation)

Castor oil-induced water and electrolyte accumulation in intestinal loop was antagonised in a dose dependent manner $(\mathrm{p}>0.05)$ when compared to the control Table 4). The doses of ESE of $C$. lutea $(43.3-173.2 \mathrm{mg} / \mathrm{kg}$ ) were found to inhibit fluid accumulation by $20-45 \%$ while the pure drug, morphine exhibit 59\% inhibition.

\section{Effect on small intestinal transit}

The administration of ESE of $C$. lutea $(43.3-173.2 \mathrm{mg} / \mathrm{kg})$, significantly reduced the intestinal propulsive movement of charcoal head in dose dependent manner ( $<0.05-0.001)$ when compared with the control group. The percentage inhibitions of intestinal transit in $C$. lutea pre-treated groups $(43.3-173.2 \mathrm{mg} / \mathrm{kg}$ ), are $18.25 \%, 38.27 \%$ and $30.52 \%$ respectively. The elucidation of mechanism of anti-diarrhoeal effects of ESE was reveal by combination of the middle dose of ESE $(86.6 \mathrm{mg} / \mathrm{kg})$ with Diphenoxylate $(0.5 \mathrm{mg} / \mathrm{kg}) ;$ ESE $(86.6 \mathrm{mg} / \mathrm{kg})$ with Isosorbide dinitrate $(150 \mathrm{mg} / \mathrm{kg})$ and ESE $(86.6 \mathrm{mg} / \mathrm{kg})$ with Yohimbine $(1 \mathrm{mg} / \mathrm{kg})$. The pure drugs antagonizes the intestinal transit time producing marked reduction of inhibition of diarrheal to $2.5 \%, 17.7 \%$ and $12.5 \%$ respectively. The result is shown in Table 5.

\section{Discussion}

Many plants with anti-diarrhoeal activities are widely distributed in Nigeria and have been reported by Soladoye et al., (2010), but very few have been subjected to pharmacological screening and elemental analysis. Human health could benefit maximally from nature if the correct amounts of the elements are taken in its ionic varieties in the right form and at the right time. The medicinal values of some plant species used in homeopathic system has been traced to the presence of $\mathrm{Ca}, \mathrm{Cr}, \mathrm{Cu}, \mathrm{Fe}, \mathrm{Mg}, \mathrm{Ca}, \mathrm{K}$ and $\mathrm{Zn}$ in plants (Perma et al., 1993). Elements have been reported to play major role as co-factors of various enzymes and in various metabolic processes (Mayer and Yykhcky, 1989). The ESE of $C$. lutea contain high amount of potassium compared to other element. The potassium may exist as potassium phosphate or sulphate. Potassium replacement during acute diarrhea prevents below-normal serum concentrations of potassium, especially in children, in whom stool potassium losses are higher than in adults (Black et al., 2003) and it is a constituent in oral rehydration salt. 
http://dx.doi.org/10.4314/ajtcam.v11i2.5

In this report, ESE of $C$. lutea produced a statistically significant reduction in the frequency and severity of diarrhoea induced by castor oil. The extract effects at all doses on the onset time of stooling was not statistically significant ( $>>0.05$ ), when compared to the control (Fig 2). The extract does not have significant effects on solid and semi-solid stool but produced a statistically significant effect $(\mathrm{p}<0.001)$ on watery stool. Thus, the extract is only effective in diarrheal state and do not affect normal stooling, probably it is not likely to produce any constipation in individual without diarrheal. The anti-diarrhea activity of the highest dose of extract is comparable to pure drugs, Morphine and Diphenoxylate.

The intra-luminal fluid accumulation induced by castor oil was also blocked by the ESE of $C$. lutea. The extract produced marked reduction in the weight and the volume of the intestinal fluid contents comparable to Morphine. However, these effects were not statistically significant. The extract pro-absorptive property may promote faster fluid absorption in the intestine or may have an anti-secretory mechanism since there was a reduction in weight and volume of stool (Yadav and Tangpu, 2007). Castor oil used as a diarrhoea-inducing agent in the experimental protocol, is known to induce diarrhoea by increasing the volume of intestinal content by preventing water absorption in the intestine (Jafri and Pasricha, 2001; Katzung, 2001). It is widely known that castor oil is metabolized into ricinoleic acid in the gut, which in turn irritates and causes inflammation in the intestinal mucosa, resulting in release of inflammatory mediators, such as prostaglandins and histamine (Luderer et al, 1980). The prostaglandins thus released promote vasodilatation, smooth muscle contraction, and mucus secretion in the small intestines (Pierce et al., 1971; Robert., 1973). The prostaglandins of the E series e.g. dinoprostone, are considered to be good diarrheagenic agents in experimental animals as well as in human beings (Jaffe, 1979). The inhibitors of prostaglandins biosynthesis are therefore considered to delay the castor oil-induced diarrheal (Pierce et al, 1971).

Castor oil-induced intestinal transit was observed (Table 5) to be significantly inhibited by ESE of $C$. lutea than standard drugs when compared to control. The percentage inhibition of the propulsive movement by the middle dose of ESE (38.27\%) is greater than that of standard drug, diphenoxylate $(33.46 \%)$. A decrease in the motility of gut muscles increases the stay of substances in the intestine. This promotes enhanced water absorption. It is therefore presumed that the reduction in the intestinal propulsive movement in the charcoal meal model may be due to antispasmodic properties of the extract (Nwidu, 2011). Yohimbine, IDN, and Diphenoxylate were employed in this study to elucidate the mechanism of action of ESE of $C$. lutea. The role of nitric oxide donors in intestinal fluid and electrolyte secretion depend on the study conditions (Izzo et al., 1998). It is established that nitric oxide synthase inhibitors (e.g. nitro-arginine methyl ester (L-NAME) reverses net fluid absorption to net secretion in mice, rats, guinea pigs, rabbits, and dogs (Adeyemi et al., 2009). In patho-physiological conditions, nitric oxide synthethase is produced at higher concentrations that evoke net secretion, thus it is said to mediate the laxative action of several secreatagogues in rats (Izzo et al., 1998). The fact that nitric oxide plays a role in the laxative effect of castor oil-induce diarrheal by inducing the release of nitric oxide (NO), which in turn mediate the generation of prostaglandin by colonic cells, evoking net fluid secretion rather than net absorption thus worsening the pathology have been reported (Mascolo et al., 1994). It has been concluded that castor oil-induced diarrheal in rats involves nitric oxide pathways based on experimental findings that IDN when administered to castor oil treated rats, prevented dose dependently the inhibitory effects of L-NAME (nitric oxide synthethase inhibitor) (Adeyemi and Akindele, 2008). In our study it was observed that the middle dose of extract gave $38.27 \%$ inhibition of intestinal transit time, was antagonised to $17.7 \%$ in the presence IDN. This in part demonstrates that nitric oxide pathways may be involved in its mechanism.

Agonist at $\alpha_{2}$-adrenergic receptor is reported to stimulate absorption and inhibit secretion of fluid and electrolyte as well as increase intestinal transit time by interacting with specific receptor on multiple sites including enteric neurons and enterocytes (DiJoseph et al., 1984). Yohimbine a specific $\alpha_{2}$-adrenergic receptor antagonist will antagonise this effect thus promoting diarrheal.

Diphenoxylate contain atropine and on the other, a muscarinic receptor antagonist, inhibits gastrointestinal motility (propulsion), reduced intestinal fluid secretion, and gastric emptying thus blunting diarrheal. The anti-diarrheal effect was found to be potentiated when the middle dose of ESE of C. lutea $(86.6 \mathrm{mg} / \mathrm{kg})$ was combined with either diphenoxylate $(0.5 \mathrm{mg} / \mathrm{kg})$ or yohimbine $(1 \mathrm{mg} / \mathrm{kg})$ producing $95 \%$ and $85 \%$ inhibition respectively in the castor oil-induced diarrheal in rats. This shows additive effects indicating that the extract may be working through the same mechanism with either diphenoxylate or Yohimbine in castor oil induced diarrheal model. Yohimbine ( $\alpha_{2}$-adrenergic receptor blocker) potentiating the activity of the extract on castor oil induced diarrheal shows that the bioactive components in the extract are not agonist at $\alpha_{2}$-adrenergic receptor. On the other hand the effects of the middle dose of ESE of C. lutea $(86.6 \mathrm{mg} / \mathrm{kg})$ on intestinal transit time was antagonised by diphenoxylate, yohimbine and IDN demonstrating that intestinal transit may be mediated via muscarinic, $\alpha_{2}$ adrenergic and nitrous oxide dependent pathways.

\section{Conclusion}

This research work revealed that ESE of $C$. lutea contains pharmacologically active substance(s) which mediates antidiarrheal properties by inhibition of intestinal motility through muscarinic, $\alpha$-adrenoceptor and nitrous oxide dependent pathway. This was not the case on castor oil-induced diarrheal in which the inhibition of diarrheal by the extract was potentiated by either diphenoxylate or yohimbine through a mechanism yet to be elucidated. $\alpha_{2}$ adrenergic agents mediating reduction of diarrheal through increase in intestinal transit time may have special role in diabetics with chronic diarrhoea, in whom autonomic neuropathy can led to loss of noradrenergic innervations (Jafri and Pasricha, 2001). The bioactive and elemental substances present in the extract could play major role in diarrheal management. These investigations gave credence to wide patronage of stem-bark extract in illicit gin or ethanol otherwise called 'akpatashi' in the ethnomedicinal management of chronic diarrhea in diabetes by the Effiks of Nigeria.

\section{Acknowledgement}

Prof Jose Anchieta and Mr. Ricardo Moutinho (both of Analytical Chemistry Dept, UNESP) assisted in the determination of elemental and anionic profile of the plant material. Dr Ray Ozolua is appreciated for the gift of morphine. Mr. Horsefall Fred Guluye, Mr. Alphonsus Ameh and Mr. Obi Cosmus are appreciated for technical assistance in Nigeria.

Declaration of interest

This study was supported by Niger Delta University Postgraduate Fellowship of Nigeria, and Khana LGA, Rivers State, Nigeria through funding for Dr Nwidu. Financial support from FAPESP at UNESP Araraquara. 


\section{References}

1. Adeyemi O.O., Akindele A.J., Ogunleye E.A.(2009). Evaluation of the antidiarrheal effect of Sanseviera liberica Gerome \& Labroy (Agavaceae) root extract .J. Ethnopharmacology, 123, 459-463.

2. Andreo, M.A, Ballesteros, K.V.R., Hiruma-Lima, C.A, Rocha, L.R.M, Brito-Souza, A.R.M, and Vilegas W. (2006). Effects of Mouriri pausa extracts on experimentally induced gastric lesions in rodents: endogenouse sulhydryls compounds and nitric oxide in gastroprotection. J. Ethnopharmacology, 107 (3), 431-41.

3. Awouters, F., Niemegeers, C.J, Lenaerts, F.M, and Janssen, P.A. (1978). Delay of castor oil diarrhoea in rats: A new way to evaluate inhibitors of prostaglandin biosynthesis. J. Pharm and Pharmacol, 30, 41-45.

4. Black, R.E, Morris S.S., and Bryce, J. (2003). Where and why are 10 million children dying every year? Lancet 2003; 361:2226-34

5. Burkill, H.M. (1984). The Useful Plants of West Tropical Africa (vol. 1, 2nd ed.) Kew, UK: Royal Botanic Gardens Drugs.

6. Dahlquist, R.L, and Knoll, J.W. (1978). Inductively Coupled Plasma-Atomic Emission Spectrometry: Analysis of biological materials and soils for major trace, and ultra-trace elements. Appl Spectroscopy, 32, 1-30.

7. DiCarlo, G.D., Mascolo N., Izzo A.A., Capasso, F., and Autore, G. (1994). Effects of quercetin On gastrointestinal tract in rats and mice. Phytother Res, 8, 4245 .

8. DiJoseph, J.F, Taylor J.A and Mir G.N. (1984). Alpha-2- receptors in gastrointestinal system a new approach. Life Sci,35, 1031-1042.

9. Ettebong, E., and Nwafor, P. (2009). In vitro antimicrobial activities of extracts of Carpolobia lutea root. Pakistan J. Pharmaceutical Sci, 22, (3), 335-338.

10. Etukudo I. (2003). Ethnobotany: Conventional and Traditional Uses of Plants. Nigeria: The Verdict Press, p. 111.

11. 11. Farthing, M.J.G. (2002). Novel targets for the control of secretary diarrheal. Gut, 50, 15-18.

12. Heinrich, M., Heneka, B., Ankli, A., Rimpler, H., Sticher, O., and Kostiza, T. (2005). Spasmolytic and antidiarrhoeal properties of the Yucatec Mayan medicinal plant Casimiroa tetrameria. J. Pharm and Pharmacol, 57, 1081-1085.

13. Iwu, M.M, and Ayanwu, B.N. (1982). Phytotherapeutic profile of Nigerian Herbs: Anti-inflammatory and Antiarthritic agents. J Ethnopharmacol, 6, (3), 263-274.

14. Izzo, A.A, Mascolo, N., and Capasso, F. (1998). Nitric oxide as a modulator of intestinal water and electrolyte transport. Dig Dis, 43, 1605-1620.

15. Jaffe, B.M. (1979). Prostaglandins and serotonin: Non-peptide diarrheagenic hormones. World J. Surgery, 3, 565-578.

16. Jafri, S., and Pasricha, P. J. (2001). Agents used for diarrhea, constipation and inflammatory bowel diseases; agents used for biliary and pancreatic diseases. In: Hardman, J.G., Limbird, L.E, Gilman, A.G, eds. Goodman\&Gilman's Pharmacological basis of therapeutic. $10^{\text {th }}$ edn, USA:McGraw Hill company Inc.1041.

17. Katzung, B.G, and Chatterjee, K. (2001). Vasodilators and treatment of angina pectoris-basic pharmacology of drugs used to treat angina. In: Katzung BG, ed. Basic Clinical Pharmacology. New York: McGraw Hill Company Inc. 183-189.

18. Linton, L.R, and Harder, L.D. (2007). Biology 315 - Quantitative Biology Lecture Notes. University of Calgary, Calgary, AB.

19. Lorke, D. (1983). A new approach to acute toxicity testing. Arch Toxicol, 54:275-287.

20. Luderer, J.R, Dermers, I.M, and Hayes, A.H Jr. (1980). Advances in Prostaglandin and Thromboxane Research. New York: Raven Press, $1633-1638$.

21. Lutterodt, G.D. (1989). Inhibition of gastrointestinal release of acetylcholine by quercetin as a possible mode of action of Psidium guajava leaf extracts in the treatment of acute diarrheal disease. J Ethnopharmacology, 25, 235-247.

22. Mascolo, N., Angel, A.I., Autore, G., Barbato, F., and Capasso, F. (1994). Nitric oxide and castor oil- induced diarrhoea. J. Pharmacol Exp Therapeutics, 263, 291295.

23. Martinez, H., Ryan, G.W, Guiscafre, H., and Gutierrez, G. (1998). An intercultural comparison of home case management of acute diarrhea in Mexico: Implications for program planners. Arch Med Res, 29, 351-360.

24. Mayer, M.I, and Yykhcky, L. (1989). The action of zinc in synaptic transmission of mouse neuronal excitability in culture of mouse hippocampus. J. Physiology, 415, 351-365.

25. Muanya C.A, and Odukoya, O.A. (2008). Lipid peroxidation as index of activity in aphrodisiac herbs. J. Plant Sci., 3, (1), $92-98$.

26. Nwafor P.A, and Bassey A.I. (2007). Evaluation of the antidiarroeal and antiulcerogenic potential of ethanol extract of Carpolobia lutea leaves in rodents. J. Ethnopharmacol, 111, (3), 619-24.

27. Nwidu L.L, and Nwafor P.A. (2009). Gastroprotective effects of leaf extracts of Carpolobia lutea (polygalaceae) G. Don. in rats. African J. Biotechnol, 8, (12), 1519.

28. Nwidu, L.L, Nwafor, P.A, da Silva V.C, Rodrigues, M.C, dos Santos L.C, and Vilegas, W.(2011a). Anti- nociceptive effects of Carpolobia lutea G. Don (Polygalaceae) leaf fractions in animal models. Inflammopharmacology, 19(4), 215-25.

29. Nwidu, ,L.L, Essiene, G.E, Nwafor, P.A., and Vilegas W. (2011b). Antidiarrheal mechanism of Carpolobia lutea leaf fractions in rats. Pharma Biol, 49 (12), 12491256.

30. Nwidu, L.L, Nwafor, P.A, and Vilegas, W. (2012a). Antimicrobial activity of Carpolobia lutea extracts and fractions. Afr J. Tradit Compliment Altern Mer, 9(3), $323-328$

31. Nwidu, L.L, Nwafor P.A, and Vilegas, W. (2012b). Neuropharmacological screening and isolation of cinnamoyl- \& coumaroul-glucosides from leaf fraction of Carpolobia lutea G. Don (Polygalaceae). Ind J. Novel Drug Delivery 4, (1), 28-37.

32. Nwidu, L.L, Nwafor, PA, and Vilegas, W. (2012c). Antiulcer Effect of ethyl acetate extract of Carpolobia lutea Leaf. J. Applied Pharm Sci., 2, (8), 233-242.

33. Nwidu, L.L, Cicili, E, and Vilegas, W. (2012d): Amino acid, Antioxidant and ionic profile of Carpolobia lutea plant extracts (Polygalaceae). Tropical J. Pharm Res. $11(5), 807-813$.

34. Nwidu, L.L, and Nwafor, P.A. (2012e). Anti-inflammatory and Antipyretic Effect of Carpolobia lutea (Polygalaceae) Leaf Extract in Rodents. Intl Res J. Pharm, $3,(5), 154-160$

35. Perman, V.S, Gupita, A.K, and Jha, H.N. (1993). Metal contents accumulation in some herbal drug. Pharm Biol, 39, (5), 384-387.

36. Pierce, N.F, Carpenter, C.C Jr, Elliott, H.L, and Greenough W.B 3rd. (1971). Effects of prostaglandins, theophylline, and cholera exotoxin upon transmucosal water and electrolyte movement in the canine jejunum. Gastroenterol, 60, 22-32.

37. Robert, A., Nezamis. J.E, Lancaster. C., Hanchar. A.J, and Klepper, M.S. (1976). Enteropooling assay: A test for diarrhea produced by prostaglandins. Prostaglandins, 11, 809-828.

38. Soladoye, M.O, Yakubu, F.A, Kola-Oladiji, K, Alabi, D.A, and Agbomeji, Y.O. (2006). The Collection, Conservation and Cultivation of Local Medicinal Plants for Natural Medicine Production. Paper presented at the Seminar/Workshop and Exhibition of Natural Medicine Products. Organized by Nigeria Traditional Medical Association, Ijebu-North in Collaboration with Faculty of Science, Olabisi Onabanjo University Agp-Iwoye, held 19-23 September, 2006.

39. Soladoye, M.O, Adetayo, M.O, Chukwuma, M.C, and Adetunji, A.N. (2011). Ethnobotanical Survey of Plants Used in the Treatment of Haemorrhoids in SouthWestern Nigeria. J. Adv Dev Res, 2, (1), 100-111.

40. Trease, G., and Evans, M. (2001): Pharmacopoeial and related drugs of biological origin. In: A Textbook of Pharmacognosy, 15th ed. London, WB Saunders, pp. 262-270.

41. Yadav, A.K, and Tangpu, V. (2007). Antidiarrheal activity of Lithocarpus dealbata and Urena lobata extracts: Therapeutic implications. Pharma Biol, 45, 223229. 